\title{
Examining the Influence of Service Recovery Satisfaction on Destination Loyalty: A Structural Equation Modelling
}

\author{
Mahadzirah Mohamad \\ Faculty of Management and Economics, Universiti Malaysia Terengganu \\ 21030 Kuala Terengganu, Malaysia
}

Ahmad Rusdi Abdullah

Faculty of Management and Economics, Universiti Malaysia Terengganu

21030 Kuala Terengganu, Malaysia

Safiek Mokhlis (Corresponding author)

Faculty of Management and Economics, Universiti Malaysia Terengganu

21030 Kuala Terengganu, Malaysia

Tel: 60-96-684-823Ｅ-mail: safiek@umt.edu.my

$\begin{array}{lc}\text { Received: October 9, } 2011 & \text { Accepted: October 27, 2011 } \\ \text { doi:10.5539/jsd.v4n6p3 } & \text { URL: http://dx.doi.org/10.5539/jsd.v4n6p3 }\end{array}$

doi:10.5539/jsd.v4n6p3

This study was funded by the Ministry of Higher Education Malaysia under the Fundamental Research Grant Scheme (FRGS) vot no. 59191.

\begin{abstract}
Total tourists' holiday experiences to a certain extent are affected by their experiences staying at a hotel. Although service providers strive for "doing it right" the first time, but service failures are inevitable in the hospitality industry. Most service providers usually undertake to recover the service failure, through efforts such as giving explanation, compensations and apology, when service failures occur. The main aim of this research is to explore the drivers of service recovery satisfaction among foreign tourists. Therefore, the primary focus of this research is to empirically test the performance of a pre-developed service satisfaction measurement in the hotel industry. The paper proposes a structural model of service recovery satisfaction on destination loyalty. Randomly-selected respondents from the population of international tourists departing from international airports were selected to be involved in the study. Initially, exploratory factor analysis (EFA) was performed to test the factorial validity of constructs. Confirmatory Factor Analysis (CFA), using AMOS, was used to test the goodness of the proposed hypothesised model designed to measure the performance of the identified factors as being attributed of service recovery satisfaction and destination loyalty. The results supported the proposed model: service recovery satisfaction has a significant influence on destination loyalty.
\end{abstract}

Keywords: Service recovery strategies, Destination loyalty, Tourism, Structural Equation Modeling (SEM)

\section{Introduction}

The tourism industry remains one of the important sectors expected to continually generate revenues and contribute to Malaysia's economic growth. In 2008, Malaysia was ranked 16th in term of global inbound tourism receipts, capturing 2\% of global market share (Economic Planning Unit, 2010). The target in the 10th Malaysia Plan is to improve Malaysia's position to be within the top ten in term of global receipts. Thus, in 2015, the sector will generate RM 115 billion in receipts and provide 2 million jobs. In order to achieve the target, the focus is on increasing the number of tourist arrivals.

Tourism is a multi-sector industry that comprises sectors such as travel, hospitality and visitor services. Frequently, a tourist's major needs while she/he is away from home are accommodation, food and beverages, and transportation. It is reported that tourists spend almost 40 percent on accommodation, 21 percent on shopping, 16 
percent on food and beverages, 12 percent on transportation and 11 percent on other items such as entertainment and sightseeing (New Straits Times, 2003). Moreover, Abdul Kadir (2010) proposed room for improvement for Malaysia to remain as one of the premier destinations in Asia such as upgrading taxi services, providing better hotel rates and hospitality attitudes to commensurate the rates charged with the quality of service delivered. Thus, it is postulated that total tourists' experience staying at a hotel to a certain extent will affect their total holiday experiences.

Malaysia's tourism business outlook is ranked as the fifth (scoring 60 out of 100) after Thailand, Singapore, Hong Kong, and China (Business Monitor International, 2010). Therefore, it is worth the effort to examine tourists' satisfaction since marketing literatures (Cronin \& Taylor, 1992; Kozak \& Rimmington, 2000; Yoon \& Uysal, 2005) provide empirical evidences that tourist satisfaction is a good predictor of customer intention to revisit and recommend the destination to other people (Destination Loyalty). In addition, destination loyalty, which is measured through "intention to return" and "willingness to recommend it" has not been thoroughly investigated (Oppermann, 2000). Instead of using the term "destination loyalty", Chen and Tsai (2007) use the term "behavioural intention" to reflect intention to revisit and the willingness to recommend. It is argued that tourist perception of a destination is influenced by their "total experience" visiting a particular destination (Buhalis, 2000) which is influenced by several service-providers enterprises, either controlled or uncontrolled (such as accommodation, food and beverages, and transportation) by the local tourism organisation.

Acknowledging that hotel service experiences to an extent affect a tourist's holiday experience, this paper attempts to uncover the influence of tourist satisfaction with respect to hotel service recovery strategies on destination loyalty. Due to the nature of services, that is, simultaneous production and consumption, the quality of service is highly dependent on the interaction between employees and customers in "real time" (Zeithmal et al., 2009). Thus, the hotel industry which is described as involving a high degree of interaction between employees and customers is more likely to be exposed to service failures (Lewis \& McCann, 2004). If service failures occur, the hotel management usually undertakes a recovery of service failures. It is postulated that successful service recovery leads to enhanced customer satisfaction and builds customer loyalty (Lewis \& McCann, 2004). Most studies (Ahmad Puad et al., 2011; Chi \& Qu, 2008; Mahadzirah et al., 2011; Yoon \& Uysal, 2005; Oom do Valle et al., 2006) on satisfaction and destination loyalty focus on examining the influence of overall travel satisfaction on destination loyalty. However, there is a lack of study that attempt to examine the link between service recovery satisfaction on destination loyalty, especially in the Malaysia tourism industry.

In order to fill the gap, the main purpose of this study is to examine the empirical evidence on causal relationship between service recovery satisfaction and destination loyalty. Therefore, a research model of service recovery satisfaction on destination loyalty was proposed and tested. The model examined the causal relationship between the constructs under study by using a Structural Equation Modeling (SEM) approach. The findings of this study would provide insights to tourism planners and marketing professionals to develop integrated destination marketing strategies to sustain the incoming of foreign tourist to Malaysia since destination marketing is complex (Dmitrovic et al., 2009). It is complex because, when tourists visit a destination, they "consume" a combination of all products, services, and experiences provided locally and therefore it requires a high degree of integration among the different service providers such as taxi drivers, hoteliers, waiters and elements of the local attraction (Buhalis, 2000).

\section{Literature Review}

\subsection{Service Recovery}

Service recovery is actions taken by service providers in response to service failure (Gronroos, 1988). Service failure is defined as service performance that falls below a customer's expectation which leads to customer dissatisfaction (Zeithmal et al., 2009). It also refers to any service-related problems experienced or perceived by consumers during service encounters (Maxham, 2001). Service failures are inevitable, especially in a situation where services are produced and consumed simultaneously. The nature of delivering services requires a high degree of contact between hotel guests and personnel at different contact points in the service-delivery process (Lewis \& McCann, 2004). Hotel service delivery is described as simultaneous consumption and production where guests' satisfaction depends on the interaction between hotel guests and employees (Zeithaml et al., 2009). Since services are mostly produced and consumed at the same time, less room is provided for employees to ensure that their service delivery would be free from problems or failures to meet guests' expectation. Hence, service failures are inevitable and apt to occur at some point in the hotel service-delivery process.

Service failure and failure of service recoveries would lead to customer switching behaviour in service industry (Chang, Ho \& Tseng, 2007). Successful service recovery has an influence on customer satisfaction (Smith et al., 
1999; Zeithaml et al., 1996) and customer loyalty (Bejou \& Palmer, 1998; Maxham \& Netemeyer, 2002). Kelley, Hoffman and Davis (1993) suggested that attempts should be made to recover from a service failure. Supporting previous works, Zeithaml et al. (2009) reported that resolving customer problems (or recovering service failures) through effective service-recovery strategies has several multiple effects such as increasing customer satisfaction and loyalty and generating positive word-of-mouth communication (post-visit behavioural).

In most cases, customers are not looking for extreme actions from the service-provider firms when service failures occur, but they expect justice and fairness in handling their complaints (Zeithaml et al., 2009). Chang, Ho and Tseng (2007) suggest that past research on service failure and recovery has presented considerable evidence of the suitability of the Justice Theory in explaining how customers evaluate service recovery efforts/strategies. Therefore, Justice Theory principles can be the basis for understanding the process of service recovery efforts/strategies undertaken by the hoteliers and its outcomes. Moreover, Lewis and McCann (2004) reported that Justice Theory was used to determine whether the service-recovery efforts/strategies undertaken by the hotel were perceived by customers as fair or otherwise which comprised:

- Distributive justice - reflects the outcome of the recovery process, for example compensation, repairs and replacement.

- Procedural justice - indicates the process undertaken to rectify the service failure, for example speed of response, accessibility and flexibility of the procedure, company policies.

- Interactional justice - referring to the manner in which the process is implemented and the customer is treated, for example provision of an apology.

Strategies to recovery service failures are grouped into the following dimensions (Lewis \& McCann, 2004):

- Apology;

- Correction;

- Empathy;

- Explanation;

- Compensation;

- Follow-up;

- Acknowledgement;

- Exceptional treatment; and

- Managerial intervention.

Therefore, we propose the following hypothesis:

H1: Service recovery strategies are manifested by several underlying observable variables.

\subsection{Destination Loyalty}

Generally, customer loyalty refers to repeat purchases or recommendation to other people (Yoon \& Uysal, 2005). Although there is no exact definition of destination loyalty (Kuusik et al., 2011), it is viewed as an intention to revisit the destination (Kozak, 2001; Jang \& Feng, 2007) and as the tourist's perception of it as a recommendable place (Chen \& Gursoy, 2001). Similarly, Kuenzel and Katsaris (2009) described post-visit behaviour as intention to return (purchase intention/loyalty) and recommendation through word-of-mouth (WOM). Therefore, destination loyalty can be described as the behavioural intention of the customers to revisit and disseminate positive word of mouth about a particular destination to others. Studies such as Cronin and Taylor (1992) and Kozak and Rimmington (2000) suggested that tourist satisfaction is a good predictor of customer intention to revisit and recommend the destination to other people. More importantly, unsatisfied tourist will not return (Dube et al., 1994). Yoon and Uysal (2005) argued that travel destinations can be considered as product, therefore the concept and degree of customer loyalty as one of the critical indicators to measure the success of a product-marketing strategy applies in travel tourism. Literatures (Chi \& Qu, 2008; Kozak \& Remington, 2000; Mahadzirah et al., 2011; Yoon \& Uysal, 2005) provide empirical evidences that confirmed a significant relationship between tourist satisfaction and destination loyalty. On these premises, this study proposes the research hypothesis as set out below:

$\mathrm{H} 2$ : The higher the tourist service delivery satisfaction, the more positive the loyalty intention. 


\section{Methodology}

This study adopted a causal research design using a cross-sectional sample survey. It was organised into three major parts. Part 1 of the questionnaire contains items to measure traveller's satisfaction with hotel service recovery strategies. The instrument to measure service recovery strategies was adapted from the study developed by Lewis and Spyrakopoulos (2001) and Lewis and McCann (2004) who developed seven and ten service recovery strategies respectively. After conducting a pilot test, a modified instrument of service recovery strategies using five dimensions of service recovery strategies (apology, correction, explanation, compensation and do nothing) on a 10-point interval scale ranging from 1 as very unsatisfied to 10 as very satisfied was formulated. The second part of the questionnaire investigates tourist destination loyalty (behavioural intention) using a 10-point interval scale ranging from 1 as not at all likely to 10 as extremely likely. Five items measuring customer loyalty were adapted from Zeithaml et al. (1996). Finally, the last part of the questionnaire contains questions pertaining to the demographic data of respondents.

Data were collected using personal interviews performed by trained interviewers at Kuala Lumpur International Airport (KLIA) and the Low Cost Carrier Terminal (LCCT) using self-administered questionnaires. The population was defined as the international tourists who visited Malaysia for leisure or business and stayed for at least one day but less than one year (Mill \& Morisson, 1985). Foreign tourists visiting Malaysia at the time of the survey were considered to be the target population. The data collecting was conducted in three phases during the periods where the arrivals of foreign tourist were high (phase 1 in July 2010, phase 2 in December 2010 and phase 3 in March 2011) and subjected to the approval of the airport authorities at the pre-determined departing areas/halls. A total of 1007 questionnaires were obtained.

Since accurate data pertaining to the optimum size of this population was not available, we engaged in creating our own sampling frame as suggested by Burns and Bush (2010). A sampling frame was created based on the returned questionnaires with the population $(\mathrm{N})$ size of 1007. Using Confidence Interval Method (Burns \& Bush, 2010 ) with $\mathrm{p}$ (estimate percent in the population) $=50 \%$, q $(100-\mathrm{p})=50 \%$, and e (acceptable sample error expressed as a percent) between $\pm 5 \%$ and $\pm 10 \%$ at $95 \%$ level of confidence, the calculated sample (n) size is between 98 and 384. According to Krejcie and Morgan (1970), when $\mathrm{N}$ is 1000, the identified $\mathrm{n}$ is 278. Hoe (2008) states any number above 200 provide sufficient statistical power to conduct data analysis using SEM. Statistical Package for Social Science (SPSS) software was used to select respondents using "Random Sample of Cases". From the created sampling frame, a total of 306 cases (representing approximately 30 percent of the population in the sampling frame) were selected for the study. After a data-cleaning process, a total of 289 cases were subjected to further analysis. Therefore, in this case the $\mathrm{n}$ size of 289 is adequate to provide statistical power for data analysis.

\section{Findings}

Analysis of the data revealed that the majority of the respondents were identified as being in the age group of between 20 - 46 years old (68\%) and male tourists comprised the majority of respondents $(60 \%)$. Most of the respondents interviewed (79\%) indicated that the purpose of their visits to Malaysia were to spend their holidays, travelling either with their spouse or friends $(69 \%)$. The majority of the respondents $(50 \%)$ indicated that this was their first trip to Malaysia and 16\% indicated that the trip was their second visit.

The collected data were subjected to exploratory factor analysis (EFA) to determine the underlying dimensions or variables of the constructs in this study. CFA and Structural Equation Modeling (SEM) were applied to the data set to test the conceptual model and examine the relationships between each pairs of variables as suggested in the hypothesis. Composite reliability analysis was conducted to measure the degree to which items are free from random error and therefore yield consistent results. The composite reliability of Service Recovery Satisfaction and Destination Loyalty are 0.89 and 0.91 respectively.

Figure 1 illustrates the structural model of Service Recovery Satisfaction and Destination Loyalty. The model suggests that there are three items comprising Service Recovery Strategies, namely apology, correction and explanation. Similarly, Destination Loyalty is manifested by three observed variables (see Table 1). Structural Equation Modelling (SEM) is applied to explain the relationships among these multiple variables (Hair et al., 2006). Insignificant p-value (0.115) suggests that the null hypothesis is failed to be rejected. Thus there is no significant difference between the observed and predicted metrics (Ho, 2006). Universally-accepted statistical indexes, such as Goodness-of-Fit Index (GFI) and Adjusted Goodness-of-Fit Index (AGFI), were used to assess the goodness-of-fit of the proposed model, with values closer to 1 indicating good fit (Byrne, 2001). The values of Goodness-of-Fit Index (GFI) and Adjusted Goodness-of-Fit Index (AGFI) attained for the proposed model are 0.98 and 0.96 respectively. It is therefore concluded that the hypothesised model proposed in the study fits the 
sample data adequately well.

Baseline comparisons indexes, another set of goodness-of-fit statistics (Normed Fit Index (NFI), Tucker-Lewis Index (TLI) and Comparative Fit Index (CFI)), are used to support the fitness of the hypothesised model. The value of Normed Fit Index (NFI), Tucker-Lewis Index (TLI) and Comparative Fit Index (CFI) ranges from 0 to 1, with values closer to 1.00 being indicative of good fit (Byrne, 2001). In this case, NFI, TLI and CFI values of $0.99,0.99$ and 0.99 respectively, are consistent in suggesting that the hypothesised model represented an adequate fit to the data. The value of Root Mean Square Error of the Approximation (RMSEA) for the proposed model is 0.048 , less than 0.08 , indicating reasonable error of approximation, implying that the model is an acceptable fit (Hair et al., 2006). Based on the above goodness-of-fit statistics, there are enough supports to conclude that the hypothesised model fits the data gathered well and further analysis can be done. The path coefficients for the full model as illustrated in Table 2 are positive and significant ( $p$-value $<0.001$ ). The findings of the study indicate that there is a positive significant relationship between Service Recovery Satisfaction and Destination Loyalty; and Destination loyalty is manifested by three underlying observable variable namely Apology, Explanation and Correction. According to the above findings, the research hypotheses are confirmed.

\section{Discussion of findings}

This study explores the influence of tourist's satisfaction with service recovery strategies deployed by hoteliers in the event of service failures or to any service-related problem, experienced or perceived by consumers during service encounters on destination loyalty. The results show that the apology, explanation and correction dimensions of service recovery strategies have a significant positive influence on destination loyalty in the context of the Malaysian tourism industry. With regard to these dimensions, Table 3 illustrates betas for each variable. These betas allow us to compare the relative importance of each independent variable (Carver \& Nash, $2005)$. In this case, the component of service recovery strategies, Apology $(\beta=0.91)$ have a greater impact on tourists' destination loyalty, followed by Explanation $(\beta=0.88)$, and Correction $(\beta=0.77)$. The findings support the premise set out by the Justice Theory which determines whether the service recovery efforts/strategies undertaken by the hotel were perceived by customers as fair or otherwise. The research indicates that to recover effectively from service failure, hoteliers must provide fair outcome, with sincere apology (interactional justice), explain to the customer how the situation can be rectified (procedural justice) and undertake to correct the service failure (distributive justice). The findings suggest that apology, explanation and correction of the problem are the necessary actions of service recovery perceived adequate to turn a dissatisfied customer into a satisfied customer.

The second part of the discussion focuses on the significant link between service recovery satisfaction and destination loyalty. The study provides tenable evidence that satisfied customers will engage in post-visit behaviour to disseminate positive word of mouth about a particular destination to others although the results indicate there is no intention to revisit. The finding fits the definition of destination loyalty by Chen and Gursoy (2001) that tourist's perception of the destination as a recommendable place. In addition, the findings of the study suggest the higher the tourists' service delivery satisfaction, the more positive the loyalty intention and this supports the previous works (Chi \& Qu, 2008; Kozak \& Remington, 2000; Mahadzirah et al., 2011; Yoon \& Uysal, 2005) which provide empirical evidences that confirmed a positive significant relationship between tourist satisfaction and destination loyalty. Therefore, the concept and degree of customer loyalty as one of the critical indicators to measure the success of product-marketing strategy applies in travel tourism.

\section{Conclusion}

Using SEM, the study empirically tested a model to examine the relationships among Service Recovery Satisfaction and Destination Loyalty. The findings support the significant relationships between the tested constructs. The empirical results of this study provide tenable evidence that the proposed structural equation model designed to consider simultaneously Recovery Strategies Satisfaction and Destination Loyalty. The study supports the claim that tourist's experience staying at hotels influenced tourist destination loyalty. Specifically, this study illustrates that successful service recovery strategies which were measured through tourist's satisfaction adopted by a hotel influence tourist destination loyalty.

Therefore, the impact of a hotel's service recovery strategies on destination loyalty should not be underestimated. The promotional strategies undertaken by the central tourism agencies perhaps would be ineffective to enhance destination loyalty if a tourist's experience visiting a travel destination was followed by a poor service recovery in the hotel. Integrated and collaborative efforts among the different individual enterprises within the sector are highly required to ensure sustainable growth of tourist arrivals. The findings suggest that the central tourism planners and marketing professionals have to undertake a collaborate approach to meet tourists' requirements 
when visiting a travel destination. Therefore, tourism bodies should be aware of a local hotel's practices in terms of service recovery and collaborate with individual hotels to ensure that the increase of foreign tourist arrival to Malaysia is sustained.

\section{References}

Abdul Kadir, L. D. (2010). Malaysia as an imagined destination: The selling points. Sintok: Universiti Utara Malaysia Press.

Ahmad Puad, M. S., Seyed Fatemeh, M. S., Azizan, M. \& Jamil, J. (2011). A critical analysis of tourist satisfaction and destination loyalty. Journal of Global Management. 2 (1), 178-183.

Bejou, D. \& Palmer, A. (1998). Service failure and loyalty: An exploratory empirical study of airline customers. Journal of Services Marketing. 12 (1), 7-22. http://dx.doi.org/10.1108/08876049810202339

Buhalis, D. (2000). Marketing the competitive destination of the future. Tourism Management. 21, 97-116. http://dx.doi.org/10.1016/S0261-5177(99)00095-3

Burns, A. C. \& Bush, R. F. (2010). Marketing research (6th ed.). Upper Saddle River, NJ: Pearson.

Business Monitor International. (2010). Malaysia Tourism Report Q2. London: Business Monitor International Ltd.

Byrne, B. M. (2001). Structural Equation Modelling with AMOS: Basic concepts, applications, and programming. Mahwah, NJ: Lawrence Erlbaum Associates.

Carver, R. H. \& Nash, J. G. (2005). Doing data analysis with SPSS version 12. Canada: Thomson Learning.

Chang, H., Ho, J. \& Tseng, C. (2007). Justice strategy options for increased customer value in service recovery strategy setting. International Journal of Business and Information. 2 (2), 241-264.

Chen, J. S. \& Gursoy, D. (2001). An investigation of tourist's destination loyalty and preferences. International Journal of Contemporary Hospitality Management. 13 (2), 79-85. http://dx.doi.org/10.1108/09596110110381870

Chen, C. F. \& Tsai, D. C. (2007). How destination and evaluative factors affect behavioral intentions? Tourism Management. 28, 1115-1122. http://dx.doi.org/10.1016/j.tourman.2006.07.007

Chi, C. G. \& Qu, H. (2008). Examining the structural relationships of destination image, tourist satisfaction and destination loyalty: An integrated approach. Tourism Management. 29, 624-636. http://dx.doi.org/10.1016/j.tourman.2007.06.007

Cronin, J. J. \& Taylor, S. S. (1992). Measuring service quality: A re-examination and extension. Journal of Marketing. 56, 55-68. http://dx.doi.org/10.2307/1252296

Dmitrovic, T., Cvelbar, L. K., Kolar, T., Brencic, M. M., Ograjensek, I. \& Zabkar, V. (2009). Conceptualizing tourist satisfaction at the destination level. International Journal of Culture, Tourism and Hospitality Research. 3 (2), 116-126.

Dube, L., Renaghan, L. \& Miller, J. (1994). Measuring customer satisfaction for strategic management. Cornell Hotel and Restaurant Administration Quarterl. 35 (1), 39-47. http://dx.doi.org/10.1016/0010-8804(94)90063-9

Economic Planning Unit (2010). Tenth Malaysia Plan 2011-2015. Putrajaya: Prime Minister's Department.

Gronroos, C. (1988). Service quality: The six criteria of good perceived service quality. Review of Business. 9(Winter), 10-13.

Hair, J. F., Black, W. C., Babin, B. J., Anderson, R. E. \& Tatham, R. L. (2006). Multivariate data analysis (6th ed.). New Jersey: Prentice-Hall International.

Hoe, S. L. (2008). Issues and procedures in adopting structural equation modelling technique. Journal of Applied Quantitative Methods. 3 (1), 76-83.

Ho, R. (2006). Handbook of univariate and multivariate data analysis and interpretation with SPSS. Boca Raton: Chapman and Hall/CRC. http://dx.doi.org/10.1201/9781420011111

Jang, S. \& Feng, R. (2007). Temporal destination revisit intention: The effects of novelty seeking and satisfaction. Tourism Management. 28 (2), 580-590. http://dx.doi.org/10.1016/j.tourman.2006.04.024

Kelley, S. W., Hoffman, K. D. \& Davis, M. A. (1993). A typology of retail failures and recoveries. Journal of Retailing. 69 (4), 429-452. http://dx.doi.org/10.1016/0022-4359(93)90016-C

Kozak, M. (2001). Repeaters' behaviour at two distinct destinations. Annals of Tourism Research. 28 (3), 
784-807. http://dx.doi.org/10.1016/S0160-7383(00)00078-5

Kozak, M. \& Rimmington, M. (2000). Tourist satisfaction with Mallorca Spain, as an off-season holiday destination. Journal of Travel Research. 38 (1), 260-269. http://dx.doi.org/10.1177/004728750003800308

Kuenzel, S. \& Katsaris, N. (2009). A critical analysis of service recovery processes in the hotel industry. TMC Academic Journal. 4 (1), 14-24.

Kuusik, A., Tiru, M., Ahas, R. \& Varblane, U. (2011). Innovation in destination marketing: The use of passive mobile positioning for the segmentation of repeat visitors in Estonia. Baltic Journal of Management. 6 (3), 378-399. http://dx.doi.org/10.1108/17465261111168000

Krejcie, R. V. \& Morgan D. W. (1970). Determining sample size for research activities. Educational and Psychological Measurement. 30, 607-610.

Lewis, B. R. \& McCann, P. (2004). Service failure and recover: Evidence from the hotel industry. International Journal of Contemporary Hospitality Management. 16 (1), 6-17. http://dx.doi.org/10.1108/09596110410516516

Lewis, B. R. \& Spyrakopoulos, S. (2001). Service failures and recovery in retail banking: The customers' perspective. International Journal of Bank Marketing. 19 (1), 37-47. http://dx.doi.org/10.1108/02652320110366481

Mahadzirah, M., Abdul Manan, A. \& Nur Izzati, A. G. (2011). A structural model of destination image, tourists' satisfaction and destination loyalty. International Journal of Business and Management Studies. 3 (2), 167-177.

Maxham, J. G. (2001). Service recovery's influence on consumer satisfaction, word-of-mouth, and purchase intentions. Journal of Business Research. 54 (1), 11-24. http://dx.doi.org/10.1016/S0148-2963(00)00114-4

Maxham, J. G. \& Netemeyer, R. G. (2002). A longitudinal study of complaining customers' evaluations of multiple service failures and recovery efforts. Journal of Marketing. 66 (4), 57-71. http://dx.doi.org/10.1509/jmkg.66.4.57.18512

Mill, R. C. \& Morisson, A. (1985). The tourism system. Hemel Hempstead: Prentice Hall.

New Straits Times (2003, June 9). Towards excellence: A tourism special, pp. 1-8.

Oom do Valle, P., Silva, J. A. \& Mendes, J. (2006). Tourist satisfaction and destination loyalty intention: A structural and categorical analysis. International Journal of Business Science and Applied Management. 1 (1), $25-44$.

Oppermann, M. (2000). Tourism destination loyalty. Journal of Travel Research. 39 (1), 78-84. http://dx.doi.org/10.1177/004728750003900110

Smith, A. K., Bolton, R. N. \& Wagner, J. (1999). A model of customer satisfaction with service encounters involving failure and recovery. Journal of Marketing Research. 36(August), 356-372. http://dx.doi.org/10.2307/3152082

Yoon, Y. \& Uysal, M. (2005). An examination of the effect of motivation ad satisfaction on destination loyalty: A structural model. Tourism Management. 26, 45-56. http://dx.doi.org/10.1016/j.tourman.2003.08.016

Zeithaml, V. A., Bitner, L. L. \& Parasuraman, A. (1996). The behavioural consequences of service quality. Journal of Marketing. 60(April), 31-46. http://dx.doi.org/10.2307/1251929

Zeithaml, V. A., Bitner, M. J. \& Gremler, D. D. (2009). Services marketing: Integrating customer focus across the firm. Singapore: McGraw-Hill Companies. 
Table 1. Items measuring service recovery strategies satisfaction and destination loyalty

\begin{tabular}{|c|c|c|c|c|}
\hline Construct & Items & Mean & $\mathrm{SD}$ & $\begin{array}{l}\text { Factor } \\
\text { loading }\end{array}$ \\
\hline \multirow{3}{*}{$\begin{array}{l}\text { Service } \\
\text { recovery } \\
\text { strategies }\end{array}$} & Correct service failures (Cor) & 6.40 & 2.10 & 0.87 \\
\hline & Explain service failures (Exp) & 6.03 & 2.12 & 0.92 \\
\hline & Apologise for service failures (Apo) & 6.16 & 2.26 & 0.92 \\
\hline \multirow{3}{*}{$\begin{array}{l}\text { Destination } \\
\text { Loyalty }\end{array}$} & $\begin{array}{l}\text { I will say positive things about Malaysia to other people } \\
\text { (BI1) }\end{array}$ & 8.25 & 1.51 & 0.91 \\
\hline & $\begin{array}{l}\text { I will recommend Malaysia to my friends and relatives as a } \\
\text { vacation destination to visit.(BI2) }\end{array}$ & 8.05 & 1.64 & 0.95 \\
\hline & $\begin{array}{l}\text { I will encourage my friends and relatives to visit Malaysia. } \\
\text { (BI3) }\end{array}$ & 7.95 & 1.82 & 0.93 \\
\hline
\end{tabular}

Table 2. Regression weights: (Group Number 1 - Default Model)

\begin{tabular}{|c|c|c|c|c|c|c|}
\hline Variable & Path & Variable & Estimate & S.E. & C.R. & $\mathrm{P}$ \\
\hline Destination Loyalty & $\leftarrow$ & $\begin{array}{l}\text { Service Recovery } \\
\text { Strategies }\end{array}$ & 0.012 & .003 & 4.643 & $* * *$ \\
\hline Explanation & $\leftarrow$ & Service Recovery & 1.000 & & & \\
\hline Apology & $\leftarrow$ & Service Recovery & 1.106 & .059 & 18.879 & $* * *$ \\
\hline Correction & $\leftarrow$ & Service Recovery & 0.871 & .055 & 15.859 & $* * *$ \\
\hline $\begin{array}{l}\text { Encourage friends and } \\
\text { relatives to visit Malaysia }\end{array}$ & $\leftarrow$ & $\begin{array}{l}\text { Destination } \\
\text { Loyalty }\end{array}$ & 1.364 & .070 & 19.538 & $* * *$ \\
\hline $\begin{array}{l}\text { Say positive things about } \\
\text { Malaysia to other people. }\end{array}$ & $\leftarrow$ & $\begin{array}{l}\text { Destination } \\
\text { Loyalty }\end{array}$ & 1.000 & & & \\
\hline $\begin{array}{l}\text { Recommend Malaysia to } \\
\text { friends and relatives as a } \\
\text { vacation destination to } \\
\text { visit. }\end{array}$ & $\leftarrow$ & $\begin{array}{l}\text { Destination } \\
\text { Loyalty }\end{array}$ & 1.270 & 0.061 & 20.707 & $* * *$ \\
\hline
\end{tabular}

Note: Significant at $p<0.001$

Table 3. Standardised Regression Weights

\begin{tabular}{|c|c|c|c|}
\hline Variable & Path & Variable & Estimate \\
\hline Destination Loyalty & $\leftarrow$ & Service recovery strategies & 0.29 \\
\hline Explanation & $\leftarrow$ & Service recovery strategies & 0.88 \\
\hline Apology & $\leftarrow$ & Service recovery strategies & 0.91 \\
\hline Correction & $\leftarrow$ & Service recovery strategies & 0.77 \\
\hline Encourage friends and relatives to visit Malaysia & $\leftarrow$ & Destination Loyalty & 0.89 \\
\hline $\begin{array}{c}\text { Say positive things about Malaysia to other people. } \\
\text { Recommend Malaysia to friends and relatives as a } \\
\text { vacation destination to visit. }\end{array}$ & $\leftarrow$ & Destination Loyalty & 0.84 \\
\hline
\end{tabular}




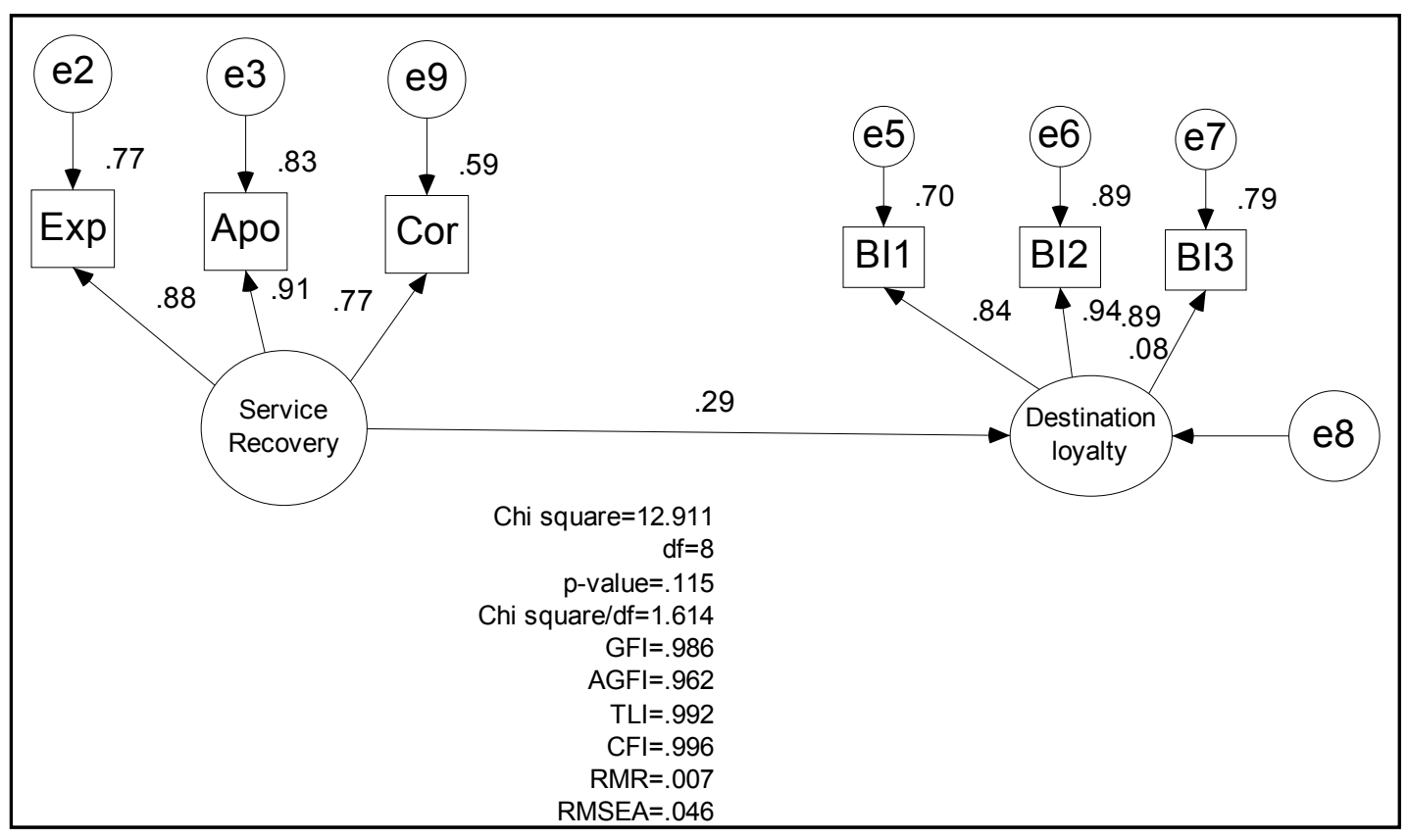

Figure 1. Structural Model of Service Recovery Satisfaction and Destination Loyalty 